Katharina Matschke $\cdot$ Luis Da Silva-Azevedo •

Ruslan Hlushchuk • Valentin Djonov • Oliver Baum

\title{
Annexins as cell-type-specific markers in the developing chicken chorionallantoic membrane
}

Received: 8 October 2005 / Accepted: 30 October 2005 / Published online: 13 December 2005

(C) Springer-Verlag 2005

\begin{abstract}
Between day E8 and E12 of embryonic development, the chicken chorioallantoic membrane (CAM) undergoes massive structural rearrangement enabling calcium-uptake from the eggshell to supply the growing embryo. However, the contribution of the various cell types of the chorionic epithelium including the capillary covering (CC) cells, villus cavity (VC) cells, endothelial-like cells, and basal cells to this developmental program is largely unknown. In order to obtain markers for the different cell types in the chorionic epithelium, we determined the expression patterns of various calcium-binding annexins in the developing chicken CAM. By reverse transcription/ polymerase chain reaction with primers deduced from nucleotide sequences available in various databases, the presence of annexin (anx) -1 , anx -2 , an $x-5$, and an $x-6$ was demonstrated at days E8 and E12. Quantitative immunoblotting with novel antibodies raised against the recombinant proteins revealed that anx-1 and anx-5 were significantly up-regulated at day E12, whereas anx -2 and anx-6 expression remained almost unchanged in comparison to levels at day E8. Immunohistochemistry of paraffinembedded sections of E12 CAM revealed anx-1 in CC cells and VC cells. Anx-2 was localized in capillaries in the chorionic epithelium and in basal cells of the allantoic epithelium, whereas anx-6 was detected in basal cells or endothelial-like cells of the chorionic epithelium and in the media of larger vessels in the mesenchyme. A 2-day exposure of the CAM to a tumor cell spheroid resulted in
\end{abstract}

K. Matschke · R. Hlushchuk · V. Djonov · O. Baum $(\bowtie)$

Institute of Anatomy, University of Berne,

Baltzerstrasse 2, CH-3009 Berne 12, Switzerland

e-mail: oliver.baum@ana.unibe.ch

Tel.: +41-31-6313445

Fax: $+41-31-6313807$

L. Da Silva-Azevedo

Institute of Physiology,

Charité-Campus Benjamin Franklin,

Free University Berlin,

Arnimallee 22, 14195 Berlin-Dahlem, Germany strong proliferation of anx-1-expressing $\mathrm{CC}$ cells suggesting that these cells participate in the embryonic response to experimental intervention. Thus, annexins exhibit complementary expression patterns and represent appropriate cell markers for the further characterization of CAM development and the interpretation of results obtained when using CAM as an experimental model.

Keywords Chorioallantoic membrane $\cdot$ Calcium resorption · Annexins · Chicken (Brown Leghorn)

\section{Introduction}

The chicken chorioallantoic membrane (CAM) is widely used as an experimental model. It has been employed in, for example, tests of the biocompatibility/toxicology of organic and inorganic materials (Spanel-Borowski 1989; Valdes et al. 2002), assessments of the ability of bacterial strains to invade epithelial barriers (Adam et al. 2002), determinations of the metastatic and developmental growth potencies of grafted tumor and embryonic tissue samples (Navarro et al. 2003), and the quantitative analysis of the angiogenic response to a defined stimulus (for reviews, see Ribatti et al. 2001; Richardson and Singh 2003).

The CAM is an extra-embryonic tissue formed by fusion of the chorion and allantois during early avian development in the egg (Patten 1950) and consists of three layers: (1) the chorionic epithelium of ectodermal origin, which is in direct contact with the shell membrane, (2) the intermediate mesenchyme consisting of both ecto- and endodermal components, and (3) the endodermal allantoic epithelium facing the allantoic cavity containing urine. The membrane is important for three biological processes (Bellairs and Osmond 1998). Because its surface is in close contact to the porous shell membrane, the CAM enables the respiratory interchange of oxygen and carbon dioxide. Furthermore, it is involved in the storage of urea, ammonia, and uric acid produced by the embryo. Finally, $\mathrm{Ca}^{2+}$ is taken up to a greater extent from the shell through the chorionic epithelium to be transported into the vasculature of the 
embryo, which initially obtains its calcium until day E10 from the yolk sac. At this time point, the $\mathrm{Ca}^{2+}$ availability in the chorionic epithelium is suddenly strongly increased, which might be correlated with changes in the expression patterns and functions of $\mathrm{Ca}^{2+}$-binding proteins.

Previous studies have demonstrated that both epithelial layers of the CAM consist of distinct cell types. Villus cavity (VC) cells and capillary covering (CC) cells are the two major components of the chorionic epithelium (Coleman and Terepka 1972). Both cell types pass through the chorionic epithelium to face the eggshell and are involved in $\mathrm{Ca}^{2+}$ mobilization and resorption (Akins and Tuan 1993). Two other cell types present in the chorionic epithelium layer are the basal cells (Hoshi and Mori 1971; Lusimbo et al. 2000) and the endothelial-like (or pericytelike) cells (Coleman and Terepka 1972; Patan et al. 1993; Shumko et al. 1988), which are functionally uncharacterized to date. Furthermore, capillaries are in close contact with the chorionic epithelium (Narbaitz 1977). The allantoic epithelium consists of three different cell types including granule-rich cells, mitochondria-rich cells, and basal cells (Coleman and Terepka 1972).

Despite the extensive use of the CAM system in cell biology, most investigators regard the CAM as a uniform structure. In particular, in angiogenesis research, investigations are restricted to determinations of the quantitative changes within the microvasculature in response to a defined stimulus. The significance of non-specific inflammatory reactions or experiment-independent proliferation (particularly of the chorionic epithelium in which the capillaries are embedded) is rarely addressed and might lead to the misinterpretation of results (Richardson and Singh 2003). To extend our knowledge of this cellular layer, we have performed a structural characterization of the chorionic epithelium of the developing chicken CAM by focusing on the expression patterns of the various annexins.

The annexins are a family of closely related $\mathrm{Ca}^{2+}$ binding and membrane-binding proteins expressed in most eukaryotic cell types (for reviews, see Gerke and Moss 2002; Moss and Morgan 2004). So far, 12 members of the annexin gene family have been detected in mammals; they are involved in many physiological processes, such as the regulation of cell growth and differentiation, apoptosis, membrane fusion, and exocytosis. They are also involved in cell signaling events and anti-inflammatory processes. In many tissues, the different annexin forms exhibit complementary expression patterns (Raynal and Pollard 1994), whereas in other cases, the annexins are co-expressed and cooperate in function (Draeger et al. 2005).

With novel antibodies, we have determined the expression patterns of four annexins in the developing chicken CAM. We have found that these annexins are specific for the different cell types of the chorionic epithelium, suggesting their involvement in different cellular functions.

\section{Materials and methods}

Tissue preparation

The shell-free culture method for chicken embryos was used to obtain CAM as described by Djonov et al. (2000). After 3 days of incubation, eggs from Brown Leghorn hens were opened and carefully transferred into plastic Petri dishes $(8 \mathrm{~cm}$ in diameter). The embryos were incubated at $37^{\circ} \mathrm{C}$ in a humid atmosphere.

CAMs were collected after the time points indicated. The CAM tissue overlying the embryo was mechanically dissected, washed three times in ice-cold phosphatebuffered saline (PBS) pH 7.4 to remove leaking blood and extravascular fluid, and then quickly subjected to biochemical and histological analyses as described below.

RNA isolation and reverse transcription/polymerase chain reaction

Total mRNA was prepared from embryonic day 8 (E8) and E12 chicken CAMs by using the RNeasy Mini kit (Qiagen, Basel, Switzerland), including proteinase $\mathrm{K}$ digestion and DNase I treatment according to the manufacturer's (Qiagen) protocol. The final mRNA concentrations thus obtained were photometrically determined. cDNA was synthesized by reverse transcription (RT) with $2 \mu \mathrm{g}$ total RNA, $1 \mu \mathrm{M}$ oligo-dT primers, and $4 \mathrm{U}$ Omniscript reverse transcriptase (Qiagen) at $37^{\circ} \mathrm{C}$ for $1 \mathrm{~h}$ according to the manufacturer's protocol. For the assessment of annexin mRNA expression, cDNA was analyzed by the polymerase chain reaction (PCR) with pairs of primers specific for each of the various chicken annexins (Table 1). In a total volume of $50 \mu 1$, 200 ng cDNA template was mixed with $5 \mu \mathrm{l} 10 \times \mathrm{Taq}$ polymerase buffer (Qiagen), primers, and dNTP solution at a concentration of $0.2 \mu \mathrm{M}$, with $2 \mathrm{mM} \mathrm{MgSO}_{4}$. During the initial denaturing step at $94^{\circ} \mathrm{C}$ for $4 \mathrm{~min}, 0.5 \mu \mathrm{l} 5 \mathrm{U} / \mu \mathrm{l} \mathrm{Taq}$ DNA polymerase (Qiagen) was added (hot start) to the mixture. The cycle profile consisted of a denaturation step at $94^{\circ} \mathrm{C}(5 \mathrm{~min})$ followed by 40 cycles with denaturation at $94^{\circ} \mathrm{C}(30 \mathrm{~s})$, annealing at $58^{\circ} \mathrm{C}(30 \mathrm{~s})$, and elongation at $72^{\circ} \mathrm{C}(90 \mathrm{~s})$.

PCR fragments were visualized by electrophoresis on a $1 \%(w / v)$ agarose (Axon, Baden-Dättwil, Switzerland) gel supplemented with $0.5 \mu \mathrm{g} / \mathrm{ml}$ ethidium bromide.

\section{Rapid amplification of 3'-cDNA ends}

Because the nucleotide sequence of anx-1 was only partially published (comprising the amino-terminal 130 amino acids) at the initiation of this study (Sidis and Horseman 1993), we performed rapid amplification of 3'cDNA ends (3'-RACE) for determination of the complete coding sequence of annexin- $1 \mathrm{cDNA}$. Aliquots with $1 \mu \mathrm{g}$ 
Table 1 Primers used for PCR analyses

\begin{tabular}{|c|c|c|}
\hline Specificity & $\begin{array}{l}\text { PCR } \\
\text { application }\end{array}$ & Nucleotide sequence \\
\hline \multirow[t]{2}{*}{ Annexin-1 } & $\begin{array}{l}\text { Forward } \\
\text { primer }\end{array}$ & 5'-ATATCCCATGGCTATGGTATCAGAATTTCTG-3' \\
\hline & $\begin{array}{l}\text { Reverse } \\
\text { primer }\end{array}$ & 5'-ATATACTCGAGTCTTCTATCAGTTCCAAGCC-3' \\
\hline \multirow[t]{2}{*}{ Annexin-2 } & $\begin{array}{l}\text { Forward } \\
\text { primer }\end{array}$ & 5'-CGATGCCATGGCTACTGTCCATGAAATTTTA-3' \\
\hline & $\begin{array}{l}\text { Reverse } \\
\text { primer }\end{array}$ & 5'-CTATACTCGAGGTCCTCTCCACCACACAGGTT-3' \\
\hline \multirow[t]{2}{*}{ Annexin-5 } & $\begin{array}{l}\text { Forward } \\
\text { primer }\end{array}$ & 5'-CGATGCCATGGCGAAGTATACAAGAGGCA-3' \\
\hline & $\begin{array}{l}\text { Reverse } \\
\text { primer }\end{array}$ & 5'-CTATACTCGAGCTCATCATCTCCACCACAGAG-3' \\
\hline \multirow[t]{2}{*}{ Annexin-6 } & $\begin{array}{l}\text { Forward } \\
\text { primer }\end{array}$ & 5'-ATATCCCATGGCACCCAAAGGAAAGGTTTAC-3' \\
\hline & $\begin{array}{l}\text { Reverse } \\
\text { primer }\end{array}$ & 5'-ATATACTCGAGGTCGTCCCCCCCGCACC-3' \\
\hline $\begin{array}{l}\text { T17 adapter primer } \\
\text { (T17AP) }\end{array}$ & & $\begin{array}{l}\text { 5'-GACTCGAGTCGACATC- } \\
\text { GATTTTTTTTTTTTTTTTT-3' }\end{array}$ \\
\hline Adapter primer (AP) & & 5'-GACTCGAGTCGACATCG-3' \\
\hline
\end{tabular}

total RNA from chicken CAM at E12 were reversetranscribed in cDNA with Omniscript RT (Qiagen) by using the T17 adapter primer (Table 1) at $37^{\circ} \mathrm{C}$ for $1 \mathrm{~h}$. Subsequent 3'-RACE was carried out with adapter primer and anx-1-specific forward primers (Table 1). The PCR protocol comprised the following steps: $94^{\circ} \mathrm{C}$ for $5 \mathrm{~min}$ (hot start) followed by 40 cycles with denaturation at $94^{\circ} \mathrm{C}$ $(30 \mathrm{~s})$, annealing at $55^{\circ} \mathrm{C}(60 \mathrm{~s})$, and elongation at $72^{\circ} \mathrm{C}$ (120 s).

Four different bands were obtained and were cloned into the vector pET-28a (Novagen, Madison, Wis., USA). Plasmid DNA was extracted from bacterial cultures to sequence the inserts by using T17 adapter primer. The plasmid containing the anx-1 insert was transformed into the expression strain (Escherichia coli BL21), and its expression was induced with isopropyl beta-D-thiogalactopyranoside. The nucleotide sequence obtained for chicken anx-1 was transferred to the NCBI database (accesion no. AY549497).

Preparation of polyclonal antibodies

Recombinant chicken anx -1 and anx -6 proteins and human anx -5 protein were used for the induction of polyclonal antibodies in rabbits. The recombinant proteins were purified from $E$. coli BL21 cultures by using the expressed His-tag. Frozen pellets were thawed on ice, suspended in lysis buffer $\left(50 \mathrm{mM} \mathrm{NaH}{ }_{2} \mathrm{PO}_{4}, 10 \mathrm{mM}\right.$

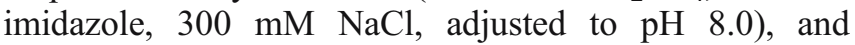
sonicated. After centrifugation $(10,000 \mathrm{~g}$ for $30 \mathrm{~min})$, the supernatant was incubated with a suspension of Ni-NTA agarose beads (Qiagen) for $1 \mathrm{~h}$ at $4^{\circ} \mathrm{C}$. After three washes in washing buffer $(50 \mathrm{mM}$ sodium phosphate $\mathrm{pH} 8.0$, $300 \mathrm{mM} \mathrm{NaCl}, 20 \mathrm{mM}$ imidazole), the protein was eluted in elution buffer (50 $\mathrm{mM}$ sodium phosphate $\mathrm{pH} 8.0$, $300 \mathrm{mM} \mathrm{NaCl}, 250 \mathrm{mM}$ imidazole). Protein concentration was measured by using a BCA protein assay reagent (Pierce, Rockford, Ill., USA), and protein purity was checked by SDS-polyacrylamide gel electrophoresis (PAGE).

Rabbits were immunized by three subcutaneous injections $(1 \times$ immunization and $2 \times$ booster $)$ of $100 \mu \mathrm{g}$ recombinant protein mixed 1:1 with GERBU Adjuvans (Gerbu, Gaiberg, Germany). Antisera were obtained 2 weeks after the second booster injection.

The preparation and characterization of the polyclonal anti-human anx-2-antibody was as described earlier (Babiychuk et al. 2000).

\section{SDS-PAGE and immunoblotting}

For the immunoblot detection of annexins, chicken CAM tissue samples were homogenized at $4^{\circ} \mathrm{C}$ in PBS pH 7.4, containing $1 \%(\mathrm{v} / \mathrm{v})$ Triton X-100 and $0.1 \%(\mathrm{v} / \mathrm{v})$ standard protease inhibitor mixture (Sigma, Munich, Germany) containing $10 \mu \mathrm{M}$ E-64, $40 \mu \mathrm{M}$ bestatin, $20 \mu \mathrm{M}$ leupeptin, $1 \mu \mathrm{M}$ aprotinin, $2 \mathrm{mM}$ EDTA, and $1 \mathrm{mM}$ 4-(2-aminoethyl) benzenesulfonyl fluoride (final concentrations). Insoluble material was removed by a centrifugation step in a bench centrifuge at 13,000 rpm for $3 \mathrm{~min}$. Subsequently, each homogenate $(50 \mu \mathrm{g}$ protein) was subjected to SDS-PAGE (BioRad, Munich, Germany) on 12.5\% gels and transferred to nitrocellulose membrane filters. After being blocked with $5 \%(\mathrm{w} / \mathrm{v})$ fat-free milk powder in washing buffer consisting of $0.1 \%(\mathrm{v} / \mathrm{v})$ Tween 20 in PBS, the blot matrices were incubated with the antibodies specific for anx-1 (1:5,000), anx-2 (1:2,000), anx-5 (1:2,000), and anx $-6(1: 5,000)$ overnight at $4{ }^{\circ} \mathrm{C}$ and, subsequently, for $1 \mathrm{~h}$ 
with a 1:5,000 dilution of peroxidase-conjugated antirabbit secondary antibody (Sigma). Bound antibodies were detected with an enhanced chemiluminescence detection kit (Supersignal, Pierce) as described by Baum et al. (2004).

\section{Two-dimensional PAGE}

E8 and E12 chicken CAMs were solubilized in 1\% (w/v) SDS in twice-distilled water for $1 \mathrm{~h}$ on ice. Insoluble material was removed by centrifugation at $20,000 \mathrm{~g}$ for $15 \mathrm{~min}$. The supernatants were subjected to acetoneprecipitation with $50 \%(\mathrm{v} / \mathrm{v})$ acetone cooled to $-20^{\circ} \mathrm{C}$. The protein pellets obtained were re-dissolved in isoelectric focusing (IEF) sample buffer consisting of $7 \mathrm{M}$ urea, $2 \mathrm{M}$ thiourea, $2 \%(\mathrm{w} / \mathrm{v})$ CHAPS, $1 \%(\mathrm{w} / \mathrm{v})$ dithiothreitol (DTT), and $2 \%(\mathrm{v} / \mathrm{v})$ ampholytes in twice-distilled water, i.e., $60 \mu \mathrm{g}$ protein in a total volume of $300 \mu \mathrm{l}$ IEF sample buffer was used for re-hydration of 17-cm-long immobilized $\mathrm{pH}-$ gradient (IPG) strips covering the $\mathrm{pH}$ range of 3-10 (BioRad, München, Germany) overnight. IEF was performed at $20^{\circ} \mathrm{C}$ in a Multiphor II chamber (Pharmacia) at $53,250 \mathrm{Vh}$ in total $(500 \mathrm{~V}$ for $5 \mathrm{~h}, 3,500 \mathrm{~V}$ for $14.5 \mathrm{~h})$.

After IEF, the IPG strips were stored at $-70^{\circ} \mathrm{C}$ until further use or were directly incubated in equilibration buffer consisting of $6 \mathrm{M}$ urea, $30 \%$ (v/v) glycerol, $2 \%(\mathrm{w} / \mathrm{v})$ SDS in $0.05 \mathrm{M}$ TRIS- $\mathrm{HCl} \mathrm{pH} \mathrm{8.8.} \mathrm{During} \mathrm{the} \mathrm{first} \mathrm{15-min}$ incubation period, the equilibration buffer was supplemented with $1 \%(\mathrm{w} / \mathrm{v})$ DTT, which was replaced with $2 \%(\mathrm{w} / \mathrm{v})$ iodoacetamide during the second 15-min incubation period.

The electrophoretic separation of proteins in the second dimension was performed on $12.5 \%$ polyacrylamide gels overnight at $6 \mathrm{~mA}$ per gel by using the Protean II-system (BioRad, München, Germany).

After SDS-PAGE, gels were either subjected to immunoblotting or silver-stained. For silver-staining, gels were first fixed in $50 \%(\mathrm{v} / \mathrm{v})$ methanol, $5 \%(\mathrm{v} / \mathrm{v})$ acetic acid in twicedistilled water for $20 \mathrm{~min}$ and then washed with twicedistilled water overnight. After reduction in sensitizer solution consisting of $0.02 \%(\mathrm{w} / \mathrm{v}) \mathrm{Na}_{2} \mathrm{~S}_{2} \mathrm{O}_{3} \times 5 \mathrm{H}_{2} \mathrm{O}$ in twice-distilled water for $1 \mathrm{~min}$, the gels were washed with twice-distilled water $(2 \times 1 \mathrm{~min})$ and then incubated in $0.1 \%$ silver nitrate in twice-distilled water for $20 \mathrm{~min}$ at $4^{\circ} \mathrm{C}$. Protein patterns were obtained after short washes in twicedistilled water for $1 \mathrm{~min}$ and three incubations in developer consisting of $0.04 \%(\mathrm{v} / \mathrm{v})$ formaldehyde, $2 \%(\mathrm{w} / \mathrm{v}) \mathrm{Na}_{2} \mathrm{CO}_{3}$ in twice-distilled water, $5 \mathrm{~min}$ each. The staining reaction was stopped by incubation in 5\% (v/v) acetic acid in twicedistilled water.

\section{Immunohistochemistry}

The embedding of chicken CAM samples in paraffin was performed as described previously (Djonov et al. 2000). After being blocked with $1 \%(\mathrm{w} / \mathrm{v})$ casein in TRIS-buffered saline (TBS) for $10 \mathrm{~min}$, sections were incubated with the primary antibody (diluted in TBS) at $4{ }^{\circ} \mathrm{C}$ overnight. The following antibodies and dilutions were used: anti-anx-1 (1:500), anti-anx-2 (1:500), anti-anx-6 (1:1,000), and antisma (alpha-smooth muscle actin; Sigma; 1:200).

Reactions were developed with an avidin-biotin horseradish-peroxidase complex (Dako, Glostrup, Denmark) and 3-amino-9-ethylcarbazole (Sigma, Buchs, Switzerland) as the substrate as described earlier (Baum et al. 2005). The sections were then counter-stained with hematoxylin and cover-slipped in Aquatex (Merck, Darmstadt, Germany). Negative controls were prepared by using nonspecific mouse and rabbit sera.

\section{Electron microscopy}

For the preparation of sections for electron microscopy, CAM areas were excised and stored in Karnowsky solution consisting of $2.5 \%(\mathrm{v} / \mathrm{v})$ glutaraldehyde, $2 \%(\mathrm{v} / \mathrm{v})$ paraformaldehyde in $0.1 \mathrm{M}$ sodium cacodylate (adjusted with $\mathrm{HCl}$ to $\mathrm{pH}$ 7.4) at $4^{\circ} \mathrm{C}$ for several days. The generation of $1-\mu \mathrm{m}-$ thick semithin sections and $80-\mathrm{nm}$ to $90-\mathrm{nm}$ ultrathin sections for ultrastructural analysis was performed as reported by Baum et al. (2005).

Generation of spheroids and their grafting onto chicken CAMs

Spheroids as three-dimensional cell aggregates used for grafting experiments were prepared as described (Korff and Augustin 1998). To obtain spheroids, 10,000 trypsinated human breast cancer MDA-MB-231 cells were mixed with $32 \mu \mathrm{l}$ DMEM containing $10 \%(\mathrm{v} / \mathrm{v})$ fetal calf serum and $8 \mu \mathrm{l}$ methocel sock solution. The cell suspension was pipetted as drops onto the cover of a Petri dish and then incubated at $37^{\circ} \mathrm{C}$ in a humid $5 \% \mathrm{CO}_{2}$ atmosphere. After a 2-day incubation, the spheroids were carefully grafted onto the surface of E10 CAMs and then incubated at $37^{\circ} \mathrm{C}$ in a humid atmosphere for 3 days.

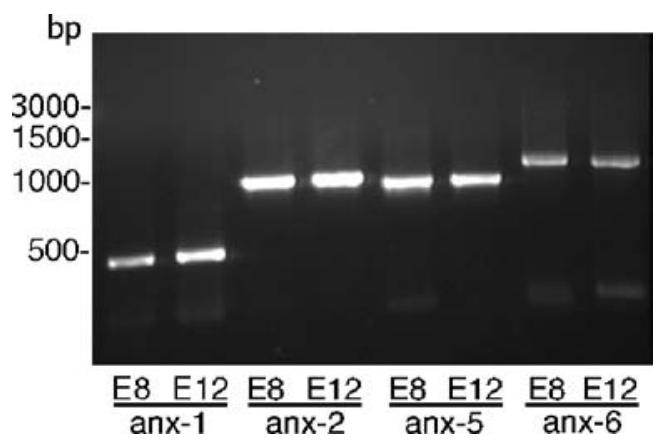

Fig. 1 RT-PCR for the detection of annexin mRNA in chicken CAM. mRNA was isolated from E8 and E12 chicken CAM and reverse-transcribed into cDNA. The presence of the various annexin cDNAs in the CAM samples was shown by PCR with primers specific for each annexin. Calculated sizes for the PCR products were 474 bp for anx $-1,1019$ bp for anx $-2,982$ bp for anx-5, and 1265 bp for anx -6 


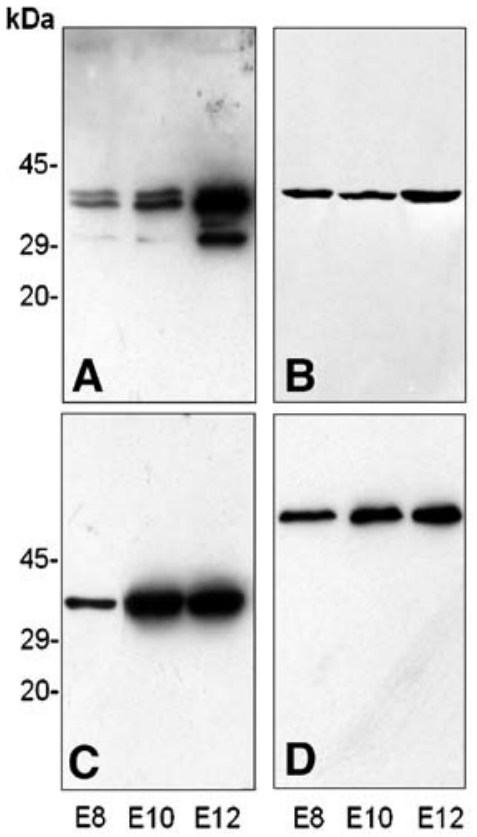

Fig. 2 Annexin-1, $-2,-5$, and -6 are expressed as proteins in the chicken CAM. SDS-PAGE and subsequent immunoblotting of equal amounts of homogenate proteins revealed that anx-1 (a), anx-2 (b), anx $-5(\mathbf{c})$, and anx-6 (d) are expressed in E8, E10, and E12 CAM at the protein level. Antibody against anx-1 recognized three different bands $(38 \mathrm{kDa}, 36 \mathrm{kDa}$, and $30 \mathrm{kDa}$; a), whereas each of the antibodies against anx-2 (38 kDa), anx -5 (36 kDa), and anx-6 $(75 \mathrm{kDa})$ were mono-specific for one band $(\mathbf{b}-\mathbf{d})$. For further discrimination of anx-1 and anx-2 immunoreactivity, immunoblotting was performed on CAM E12 samples after two-dimensional

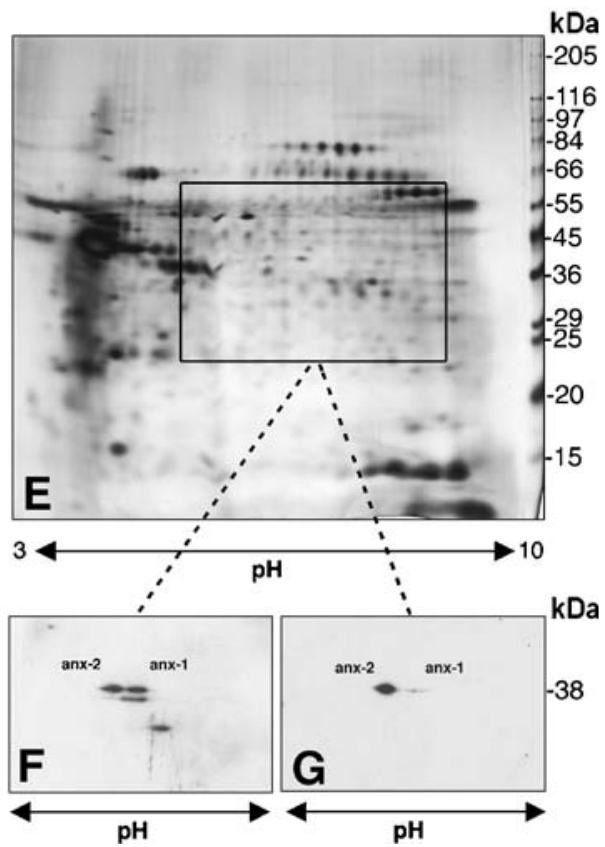

PAGE and demonstrated that the anx -1 antibody bound to anx -1 and anx -2 and to two smaller proteins (f), whereas the antibody against anx -2 was almost specific for an $\mathrm{x}-2$ (g). e Silver-staining of a gel in which the proteins of the CAM day E12 were separated by two-dimensional PAGE showing the area of the immunoblots in insets $\mathbf{f}, \mathbf{g}$. Note the variable expression of the bands after SDSPAGE (a-d) demonstrating that the concentrations of anx -1 and anx -5 , but not of anx -2 and anx -6 , are strongly up-regulated during CAM development at E8-E12
Fig. 3 Annexins are localized in various cell types in the chicken CAM. Immunohistochemistry on paraffin sections of E12 CAM localized anx -1 to a subset of chorionepithelial cells located apically and laterally in the capillaries (a). Immunoreactivity for anx-2 was clustered in capillaries in the chorionic epithelial layer and in basal cells of the allantoic epithelial layer (b), whereas anx -6 was detected in the middle part of the chorionic epithelial layer and in the media of larger arteries and veins (c). Smooth muscle cell actin (sma) as a control was exclusively expressed in the media of larger feeding arteries (d). Note that the anx -1 , anx -6 , and sma immunohistochemistry was performed on serial sections. Insets Erythrocytes (arrows) in capillaries. Bars $100 \mu \mathrm{m}(\mathbf{d}), 20 \mu \mathrm{m}$ (inset in a)
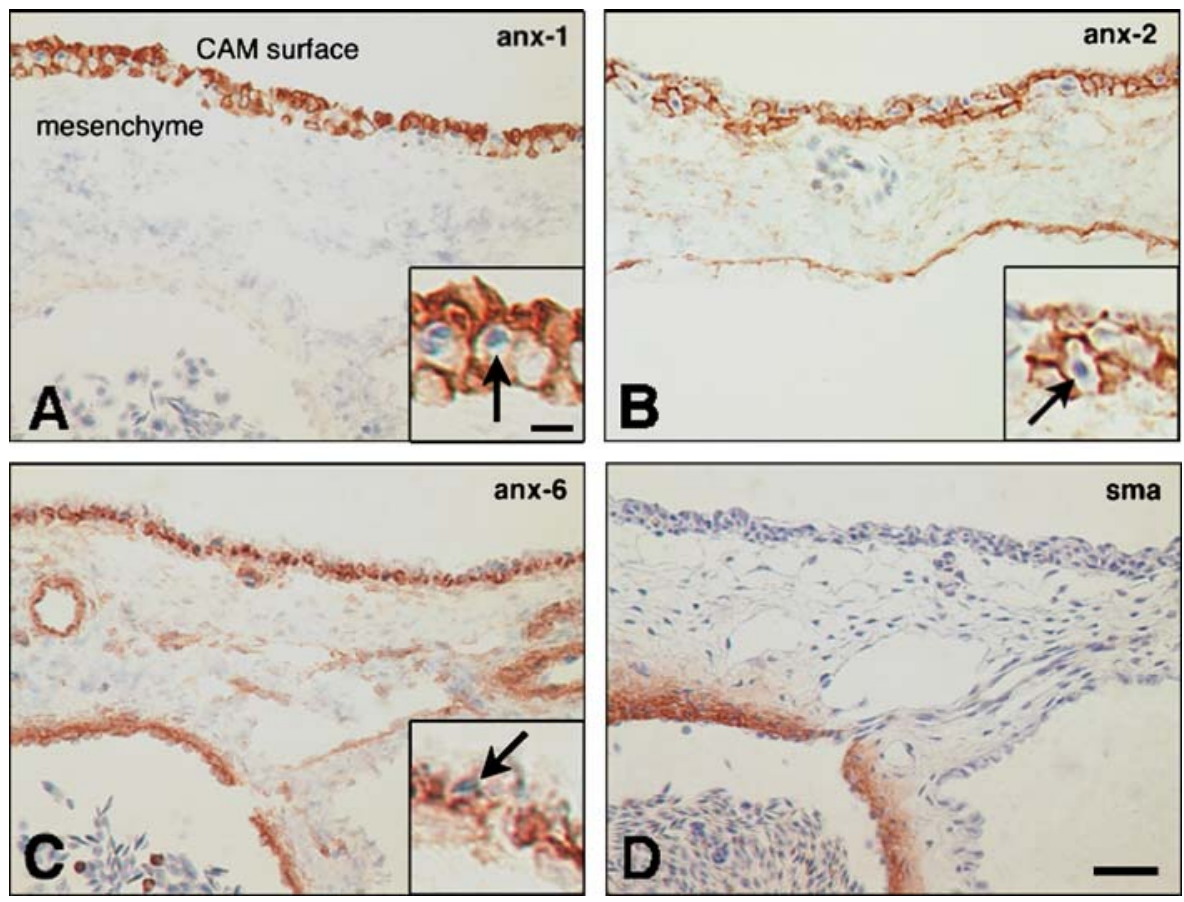


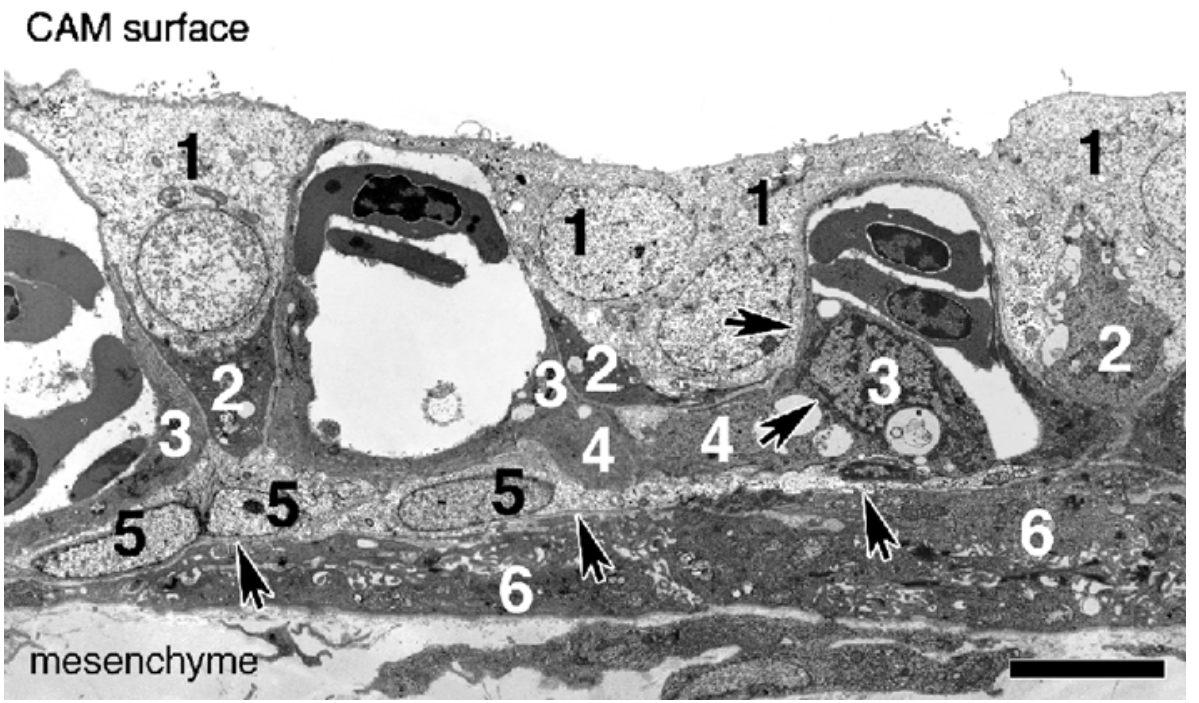

Fig. 4 Electron-microscopic analysis of ultrathin sections of E12 CAM revealed five different cell types in the chorionic epithelium of the CAM. Cytoplasm-rich cells with large nuclei representing CC cells were found apically and between the capillaries (1). Darker VC cells (2) were also interspersed between capillaries consisting of

\section{Results}

The presence of annexins in the developing chicken CAM was first investigated by RT-PCR. This analysis was performed with primers specific for anx -1 , anx -2 , anx -5 , and anx-6, since chicken cDNA sequences were available for these annexins in public databases (SwissProt, NCBI) at endothelial cells (3) separated by a basement membrane (arrows) from endothelial-like cells (4) in close contact to basal cells (5). Filipodia-containing cells $(6)$ accumulated in the mesenchyme under a second basement membrane (arrows). Bar $10 \mu \mathrm{m}$
Fig. 5 Anx-1-expressing CC cells proliferate at the chorionepithelial layer in response to grafted tumors. a, b Immunohistochemistry on serial sections demonstrated that the chorionic epithelium of E12 CAM had significantly proliferated (arrows prominent chorionic epithelial cells) after a 2-day exposure to a grafted tumor spheroid (T). Most of the chorionic epithelial cells expressed anx -1 (a) and only a few anx-6 (b). c-e Further ultrastructural analysis showed that the apical (c), central (d), and basal (e) sites of the enlarged chorionic epithelium were mainly composed of cytoplasm-rich cells with large nuclei ( 1 presumed CC cells) and capillary endothelial cells (3). Occasionally, degenerated cells with apoptotic depositions were observed (2). Bars $20 \mu \mathrm{m}(\mathbf{b}), 10 \mu \mathrm{m}(\mathbf{e})$

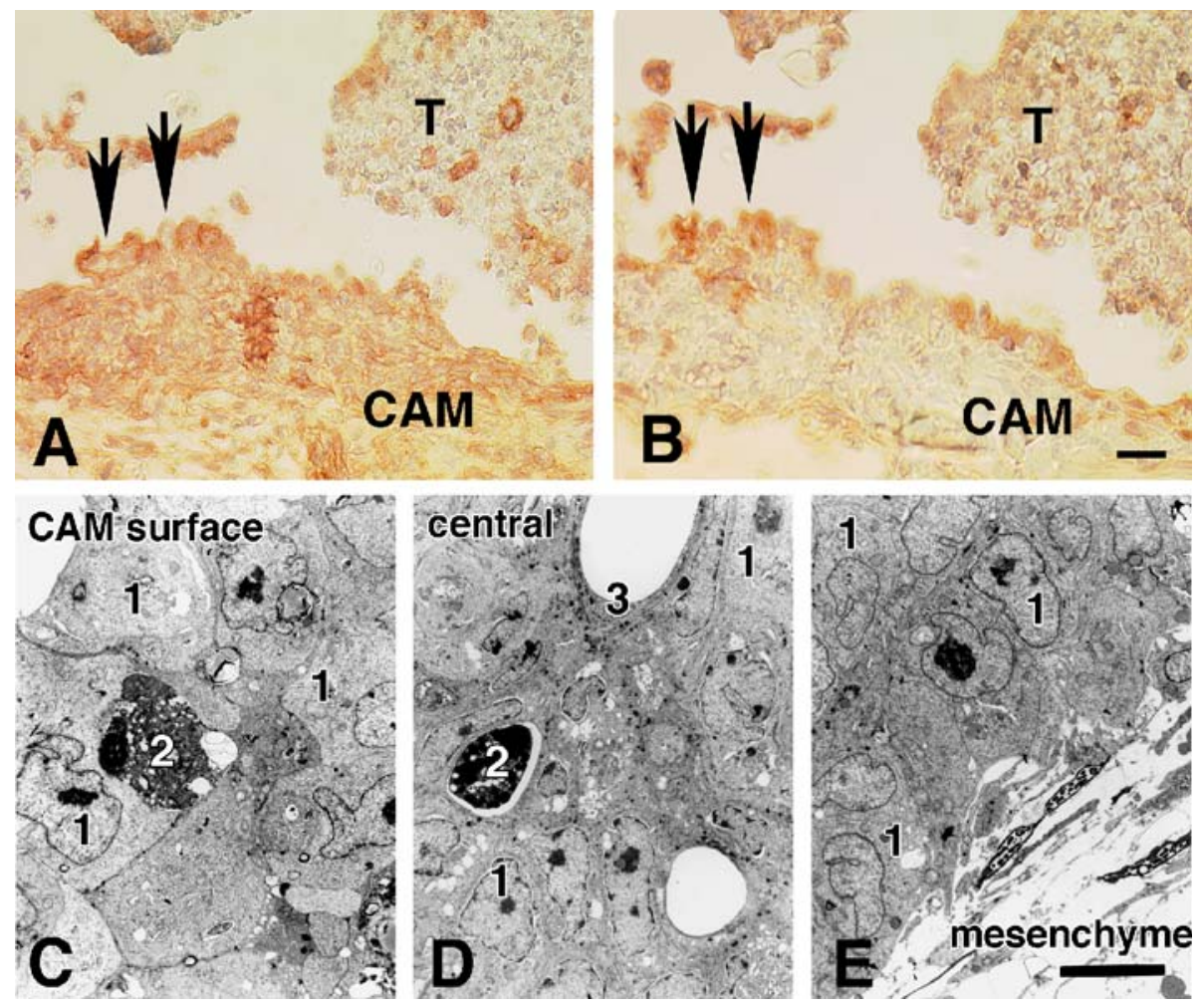

the initiation of the study. As shown in Fig. 1, RT-PCR on samples of CAM at E8 and E12 resulted in the amplification of a single DNA fragment for each of these four annexin cDNAs investigated. In all cases, the sizes of the DNA fragments obtained corresponded to the sizes calculated. These data indicated that anx -1 , anx -2 , anx -5 , and anx-6 were expressed in the chicken CAM at E8 and E12. 
The analysis of the annexin expression patterns was continued at the protein level by using antibodies. Because chicken anx -5 and anx -2 both show a high sequence similarity to their human counterparts, we used polyclonal antibodies against human anx -5 and porcine anx -2 . We prepared polyclonal antibodies against chicken recombinant anx -1 and an $x-6$. Since, however, the anx -1 nucleotide sequence had only partially been published, we first performed 3' RACE to obtain a clone containing the complete coding sequence of chicken anx -1 . Comparison of the cDNA deduced primary structures revealed that chicken anx -1 contained 342 amino acids with a sequence similarity of $76 \%$ to human anx -1 . Furthermore, amino acid sequence analysis showed that chicken anx-1 was $69 \%$ similar to chicken anx $-2,58 \%$ to chicken anx -5 , and $59 \%$ to chicken anx -6 .

With the antibodies against the four annexins, immunoblotting after SDS-PAGE was performed on detergent extracts of E8, E10, and E12 CAMs (Fig. 2a-d). In these samples, the antibodies against anx-2 (band at $38 \mathrm{kDa}$ ), anx -5 (band at $36 \mathrm{kDa}$ ), and anx -6 (band at $75 \mathrm{kDa}$ ) each recognized only one band. In contrast, the anti-anx-1 antibody bound to three bands $(38 \mathrm{kDa}, 36 \mathrm{kDa}$, and $30 \mathrm{kDa}$ ). The gels were loaded with identical amounts of proteins to render the quantitative expression patterns of the annexins investigated. During CAM development between days E8 and E12, both anx-1 and anx -5 were strongly upregulated, whereas the anx -6 message was only slightly elevated. The expression of anx -2 was apparently not changed. Control immunoblotting experiments revealed that all annexins were solubilized by Triton X-100 because no immunoreactive bands were detectable in insoluble pellets after being boiled in 1\% SDS (data not shown).

Because the size of the anx-1 band detected in immunoblots resembled that of anx -2 , we continued to characterize the specificity of these antibodies by immunoblotting after two-dimensional PAGE (Fig. 2e-g). As shown in Fig. $2 \mathrm{f}$, the antibody against anx -1 recognized four proteins in the two-dimensional immunoblot: two 38$\mathrm{kDa}$ spots with slightly differing $\mathrm{pI}$ (6.9 and 7.1), a 36-kDa spot, and a $30-\mathrm{kDa}$ spot. The anti-anx-2 antibody bound only to the two $38-\mathrm{kDa}$ spots, with higher specificity for the more acidic protein (Fig. 2g). Based on calculations that the $\mathrm{pI}$ of anx -1 is 7.1 and that of anx -2 is 6.9 , the anti anx -1 antibody recognized anx -1 and anx -2 , whereas the antianx -2 antibody was almost specific for anx -2 .

Immunohistochemistry with anti-annexin antibodies was performed on paraffin-embedded sections of E12 CAM. As shown in Fig. 3, anx-1 immunoreactivity was restricted to a subset of cells in the chorionic epithelium located at apical and lateral sites of the capillaries. Immunoreactivity for anx -2 was found at two sites: in capillaries in the chorionic epithelial layer and in basal cells of the allantoic epithelial layer. Anx-6 was detected in the middle part of the chorionic epithelial layer (below capillaries) and in the media of larger arteries and veins, whereas smooth muscle cell actin (used as a control) was exclusively expressed in the media of larger feeding arteries. The anx -5 antibody only functioned on immuno- blots and did not produce staining in immunohistochemistry (data not shown).

Electron-microscopic analysis of ultrathin sections of E12 CAM revealed that the chorioepithelial layer was composed of five different cell types (Fig. 4). Apical to and lateral of the capillaries, cytoplasm-rich cells with large nuclei representing $\mathrm{CC}$ cells were found at the ultrastructural level. VC cells were recognized as dark cells, although they were cut only basally in many cases. These cells were interspersed regularly between capillaries consisting of thin endothelial cells. Separated by a basement membrane, endothelial-like cells lay in close contact to the capillaries and also to the cytoplasm-rich basal cells in the lowest layer of the chorionic epithelium. Filipodia-containing cells were observed below a second basement membrane and therefore belonged to the mesenchyme.

Tumor cell spheroids grafted onto the CAM provoked a strong defense reaction detected as significant thickening of the chorionic epithelium (Fig. 5) compared with the nonstimulated CAM (Figs. 3, 4). Immunohistochemistry was performed on serial paraffin-embedded sections from an E12 CAM after a 2-day exposure to tumor cell spheroids (Fig. 5). Most of the chorionic epithelial cells expressed anx-1, whereas only a few cells were anx-6-immunoreactive. Furthermore, electron-microscopic analysis showed that the thickened chorionic epithelial layer was mainly composed of CC cells. Single cells of unknown origin that clearly had undergone apoptosis were also regularly observed.

\section{Discussion}

In the present study, we have determined the expression patterns of four annexins (anx -1 , anx -2 , anx -5 , and anx-6) in the developing chicken CAM between E8 and E12. At this time, the chorionic epithelium of the chicken CAM undergoes massive structural rearrangement. The originally bilayered chorionic epithelium differentiates and proliferates forming a multilayer that subsequently lies in close contact with the acellular inner shell membrane. This spatial proximity allows the cells of the chorionic epithelium to mobilize $\mathrm{Ca}^{2+}$ from the eggshell to supply the growing embryo (Akins and Tuan 1993). Simultaneously, the capillary network expands, first by sprouting and then by intussusceptive growth to form, at E10, a dense plexus that finally invaginates into the chorionic epithelium (Djonov et al. 2003; Patan et al. 1993). This movement of the capillary system and the simultaneous thinning of the endothelial cells greatly reduce the thickness of the diffusion barrier.

Twelve different annexin forms have been described in eukaryotic cells (for reviews, see Gerke and Moss 2002; Moss and Morgan 2004), but nucleotide sequences were available for only four chicken annexins at the initiation of this study. Using these sequence data, we performed RTPCR analysis demonstrating the presence of anx -1 , anx -2 , anx -5 , and anx -6 in the chicken CAM at E8 and E12. For further characterization of the expression patterns of these annexins, polyclonal antibodies were raised against the 
recombinant proteins. In immunoblots after SDS-PAGE on CAM homogenates, the anti-anx -5 and anti-anx-6 antibodies recognized only one band with sizes corresponding to the theoretical values ( $75 \mathrm{kDa}$ and $36 \mathrm{kDa}$, respectively) suggesting that these two antibodies were monospecific for their antigens. The anx -1 antibody bound to three bands $(38 \mathrm{kDa}, 36 \mathrm{kDa}$, and $30 \mathrm{kDa})$. The two smaller immunoreactive proteins presumably represented proteolytic fragments of anx-1, as has also been described by others (Movitz and Dahlgren 2000). A partial degradation with impact on biological activity has been also observed for anx-2 (Babiychuk et al. 2002). However, because anx -1 is more susceptible to this posttranslational modification (Babiychuk et al. 2002), only anx-1 and not anx-2 fragmentation might have been detected in this study.

Because intact anx -1 and an -2 have a similar size $(38 \mathrm{kDa})$ and show the highest grade of sequence similarities within the chicken annexin gene family, we performed two-dimensional immunoblotting to determine the specificity of the antibodies prepared against these two annexins. Both antibodies recognized anx -1 and anx -2 . However, anti-anx -1 antibody binding was greater to anx1 than to anx -2 , if one considers all immunoreactive anx -1 forms (intact and degraded). The anti-anx-2 antibody bound with significantly higher affinity to anx -2 than to anx -1 . Thus, all the antibodies used in this study showed no or only limited cross-reactivity against further chicken CAM proteins including the other annexin forms.

Although the cellular composition of the chorionic epithelium of the CAM has been clarified in several ultrastructural studies (Ganote et al. 1964; Leeson and Leeson 1963; Skalinsky and Kondalenko 1964), the functional relevance of the different cell types is still mostly unknown. VC cells represent an intensively characterized cell type of the chorionic epithelium and contain electron-dense cytoplasm with numerous mitochondria and sub-apical vesicles (Coleman and Terepka 1972; Owczarzak 1971). These VC cells produce and secrete, into the extrachorionic space, protons that are responsible for dissociation of calcium carbonate complexes in the eggshell. Furthermore, VC cells are also important for the acid-base balance of the embryo. To carry out these functions, VC cells contain high concentrations of carbonic anhydrase CAII (Anderson et al. 1981;
Gabrielli et al. 2001; Tuan 1980), vacuolar-type $\mathrm{H}^{+}$-AT Pase (Narbaitz et al. 1995), and anion exchanger-1, which is accumulated in the basolateral plasma membrane domain (Gabrielli et al. 2004).

The second common cell type of the chorionic epithelium, designated the $\mathrm{CC}$ cell, covers almost the total apical surface. With their thin cytoplasmic extensions, these almost organelle-free cells are separated from the capillary plexus (Coleman and Terepka 1972). CC cells take up $\mathrm{Ca}^{2+}$ from the eggshell and release these ions into the microvasculature after transcytosis. Consequently, CC cells express as markers transcalcin (a vitamin K-dependent $\mathrm{Ca}^{2+}$-transporter) and a $\mathrm{Ca}^{2+}$-activated $\mathrm{Mg}^{2+}$-dependent ATPase (Akins and Tuan 1993). To our knowledge, specific biochemical properties or molecular markers of the other cell types of the chorionic epithelium (basal cells, endothelial-like cells, and capillary endothelial cells) have not been described so far. However, endothelial-like cells contribute to intussusceptive-growth angiogenesis (Patan et al. 1993).

Immunohistochemistry has revealed anx-1 immunoreactive sites regularly in cells apical of the capillary plexus and interspersed between two capillary sinus in the chorionic epithelium. This localization is typical for VC cells and CC cells. Massive proliferation of VC cells and CC cells at E10 (Coleman and Terepka 1972) leads to an higher concentration of these two cell types in the CAM and, consequently, the content of their associated proteins in homogenates. Because the level of anx -1 is strongly elevated in immunoblots on CAM homogenates after E10, we conclude that anx -1 is a marker of CC cells and VC cells.

At all the time points investigated (E8-E12), anx-2immunoreactive sites are exclusively present in endothelial cells of the chorionic epithelium and basal cells of the allantoic epithelium. These cells do not undergo rearrangement to any significant degree during embryonic development as is reflected by the almost unchanged levels of anx-2 detected in immunoblots. These data suggest that anx -2 is a marker of the capillary endothelium of the chorionic layer.

Unfortunately, antibodies against anx-5 worked in immunoblots only. Our analysis revealed that the anx -5 concentration increased after day 8 . Because such an upregulation was also seen for anx -1 , we speculate that anx -5

Table 2 Summary of biochemical properties, localization, and developmental regulation $(+++$ strong, + positive, - none $)$ of annexins in chicken CAM

\begin{tabular}{|c|c|c|c|c|c|c|c|}
\hline $\begin{array}{l}\text { Annexin } \\
\text { type }\end{array}$ & $\begin{array}{l}\text { Accession } \\
\text { number }\end{array}$ & $\begin{array}{l}\text { Amino } \\
\text { acids }\end{array}$ & $\begin{array}{l}\text { RT- } \\
\text { PCR }\end{array}$ & $\begin{array}{l}\mathrm{Mr} \\
(\mathrm{k})\end{array}$ & $\mathrm{pI}$ & Localization in E8-E12 CAM & $\begin{array}{l}\text { Regulation during E8-E12 } \\
\text { development }\end{array}$ \\
\hline $\begin{array}{l}\text { Annexin- } \\
1\end{array}$ & AY549497 & 342 & Yes & 38.4 & 7.1 & $\begin{array}{l}\text { Apical part and along capillaries in the } \\
\text { chorionepithelial layer }\end{array}$ & +++ \\
\hline $\begin{array}{l}\text { Annexin- } \\
2\end{array}$ & NM_205351 & 339 & Yes & 38.5 & 6.9 & $\begin{array}{l}\text { Capillary endothelial cells } \\
\text { Basal part of the allantoisepithelial layer }\end{array}$ & - \\
\hline $\begin{array}{l}\text { Annexin- } \\
5\end{array}$ & U01680 & 321 & Yes & 36.1 & 5.6 & Not determined & +++ \\
\hline $\begin{array}{l}\text { Annexin- } \\
6\end{array}$ & S67466 & 671 & Yes & 75.1 & 5.4 & $\begin{array}{l}\text { Basal part of the chorionepithelial layer } \\
\text { Smooth muscle of the arterial media }\end{array}$ & + \\
\hline
\end{tabular}


is also expressed in epithelial cells of the chorionic epithelium as these are the only cells significantly proliferating at this time period of embryonic development (Coleman and Terepka 1972). However, immunohistochemistry data are needed to confirm this suggestion.

Immunohistochemistry has demonstrated strong anx -6 immunoreactivity exclusively in cells located under the capillary plexus. At this site, basal cells and endotheliallike cells are present, neither of which undergo proliferation (Coleman and Terepka 1972). Additional anx-6 immunoreactivity has been observed in the smooth muscle cell layer of the larger vessels in the mesenchyme; these are also not augmented during E8-E12 development. In accordance with these data, immunoblotting levels of anx -6 remain constant. In this study, we have not been able to determine whether anx -6 is expressed in basal cells or in endothelial-like cells. However, because there is no marker for both of these cell types, our detection of anx -6 as being specifically expressed in one of these two cell types of the chorionic epithelium is the first report of their biochemical characterization.

The biochemical properties and immunohistochemically determined expression patterns of chicken annexins in the developing CAM as obtained in this study are summarized in Table 2. For validation, particularly of the exact assignment of immunoreactivity to defined cell types, immunoelectron microscopy should be applied.

The expression of defined annexins cannot be assigned to special cell types because each annexin might be expressed in multiple cell types. Furthermore, the various functions of all the different annexins are only partially understood. Thus, the functions of the four annexins in the chicken chorionic epithelium during E8-E12 development cannot be deduced by analysis of their cellular expression patterns.

However, anx-1 is often present in cells that are involved in anti-inflammatory and immunomodulation reactions, e.g., in macrophages where it inhibits the inducible form of nitric oxide synthetase and phospholipase A2 activity (Parente and Solito 2004). This observation agrees with our results of the strong proliferation of anx-1-expressing CC cells in the chorionic epithelium in response to grafted tumor spheroids; this might represent part of the reaction of the chicken CAM to invading pathogens (Sweeny and Bather 1968) or experimental intervention. Interestingly, degenerated cells in the CAM (similar to those that we have seen) have previously been identified as apoptotic endothelial cells that perish after exposure to pathogens (Sweeny and Bather 1968). We would also like to mention that anx-2 is found in endothelial cells of many tissues (Kim and Hajjar 2002), similar to the findings of the present study. This localization is in accordance with the function of anx-2 as an inhibitor of fibrinolysis and a modulator of angiogenesis (Hayes and Moss 2004).

In conclusion, our study shows that anx -1 , anx -2 , anx5 , and anx -6 exhibit complementary expression patterns in the chorionic epithelium. This knowledge should aid further functional characterization of the various cell types in the developing chicken CAM.

Acknowledgements The skilful technical support of Bettina de Breuyn, Regula Buergy, and Christina Sala is gratefully acknowledged. We thank Dr. Katia Monastyrskaya for providing the antiannexin-2 antibody and for helpful discussions.

\section{References}

Adam R, Mussa S, Lindemann D, Oelschlaeger TA, Deadman M, Ferguson DJ, Moxon R, Schroten H (2002) The avian chorioallantoic membrane in ovo-a useful model for bacterial invasion assays. Int J Med Microbiol 292:267-275

Akins RE, Tuan RS (1993) Transepithelial calcium transport in the chick chorioallantoic membrane. I. Isolation and characterization of chorionic ectoderm cells. J Cell Sci 105:369-379

Anderson RE, Gay CV, Schraer H (1981) Ultrastructural localization of carbonic anhydrase in the chorioallantoic membrane by immunocytochemistry. J Histochem Cytochem 29:1121-1127

Babiychuk EB, Monastyrskaya K, Burkhard FC, Wray S, Draeger A (2002) Modulating signaling events in smooth muscle: cleavage of annexin 2 abolishes its binding to lipid rafts. FASEB J 16:1177-1184

Babiychuk VS, Draeger A, Babiychuk EB (2000) Smooth muscle actomyosin promotes $\mathrm{Ca}^{2+}$-dependent interactions between annexin VI and detergent-insoluble glycosphingolipid-enriched membrane domains. Acta Biochim Pol 47:579-589

Baum O, Djonov V, Ganster M, Widmer M, Baumgartner I (2005) Arteriolization of capillaries and FGF-2 upregulation in skeletal muscles of patients with chronic peripheral arterial disease. Microcirculation 12:527-537

Baum O, Da Silva-Azevedo L, Willerding G, Wockel A, Planitzer G, Gossrau R, Pries AR, Zakrzewicz A (2004) Endothelial NOS is main mediator for shear stress-dependent angiogenesis in skeletal muscle after prazosin administration. Am J Physiol Heart Circ Physiol 287:H2300-H2308

Bellairs R, Osmond M (1998) The atlas of chick development. Academic Press, San Diego

Coleman JR, Terepka AR (1972) Fine structural changes associated with the onset of calcium, sodium and water transport by the chick chorioallantoic membrane. J Membrane Biol 7:111-127

Djonov V, Baum O, Burri PH (2003) Vascular remodeling by intussusceptive angiogenesis. Cell Tissue Res 314:107-117

Djonov V, Schmid M, Tschanz SA, Burri PH (2000) Intussusceptive angiogenesis: its role in embryonic vascular network formation. Circ Res 86:286-292

Draeger A, Wray S, Babiychuk EB (2005) Domain architecture of the smooth-muscle plasma membrane: regulation by annexins. Biochem J 387:309-314

Gabrielli MG, Cox JV, Materazzi G, Menghi G (2004) Cell typespecific and developmentally regulated expression of the AE1 anion exchanger in the chicken chorioallantoic membrane. Histochem Cell Biol 121:189-199

Gabrielli MG, Materazzi G, Cox JV, Menghi G (2001) Specialised cell types in the chorioallantoic membrane express carbonic anhydrase during chick embryogenesis. J Anat 198:229-238

Ganote CE, Beaver DL, Moses L (1964) Ultrastructure of the chick chorio-allantoic membrane and its reaction to inoculation trauma. Lab Invest 13:1575-1589

Gerke V, Moss SE (2002) Annexins: from structure to function. Physiol Rev 82:331-371

Hayes MJ, Moss SE (2004) Annexins and disease. Biochem Biophys Res Commun 322:1166-1170

Hoshi H, Mori T (1971) The fine structure of the chorionic epithelium of chick embryo. Arch Histol Jpn 33:45-58

Kim J, Hajjar KA (2002) Annexin II: a plasminogen-plasminogen activator co-receptor. Front Biosci 7:d341-d348 
Korff T, Augustin HG (1998) Integration of endothelial cells in multicellular spheroids prevents apoptosis and induces differentiation. J Cell Biol 143:1341-1352

Leeson TS, Leeson CR (1963) The chorio-allantois of the chick. Light and electron microscopic observations at various times of incubation. J Anat 97:585-595

Lusimbo WS, Leighton FA, Wobeser GA (2000) Histology and ultrastructure of the chorioallantoic membrane of the mallard duck (Anas platyrhynchos). Anat Rec 259:25-34

Moss SE, Morgan RO (2004) The annexins. Genome Biol 5:219

Movitz C, Dahlgren C (2000) Endogenous cleavage of annexin I generates a truncated protein with a reduced calcium requirement for binding to neutrophil secretory vesicles and plasma membrane. Biochim Biophys Acta 1468:231-238

Narbaitz R (1977) Structure of the intra-chorionic blood sinus in the chick embryo. J Anat 124:347-354

Narbaitz R, Bastani B, Galvin NJ, Kapal VK, Levine DZ (1995) Ultrastructural and immunocytochemical evidence for the presence of polarised plasma membrane $\mathrm{H}(+)$-ATPase in two specialised cell types in the chick embryo chorioallantoic membrane. J Anat 186:245-252

Navarro M, DeRuiter MC, Carretero A, Ruberte J (2003) Microvascular assembly and cell invasion in chick mesonephros grafted onto chorioallantoic membrane. J Anat 202:213-225

Owczarzak A (1971) Calcium-absorbing cell of the chick chorioallantoic membrane. I. Morphology, distribution and cellular interactions. Exp Cell Res 68:113-129

Parente L, Solito E (2004) Annexin 1: more than an antiphospholipase protein. Inflamm Res 53:125-132

Patan S, Haenni B, Burri PH (1993) Evidence for intussusceptive capillary growth in the chicken chorio-allantoic membrane (CAM). Anat Embryol (Berl) 187:121-130

Patten B (1950) Early embryology of the chick. Lewis, London
Raynal P, Pollard HB (1994) Annexins: the problem of assessing the biological role for a gene family of multifunctional calciumand phospholipid-binding proteins. Biochim Biophys Acta 1197:63-93

Ribatti D, Nico B, Vacca A, Roncali L, Burri PH, Djonov V (2001) Chorioallantoic membrane capillary bed: a useful target for studying angiogenesis and anti-angiogenesis in vivo. Anat Rec 264:317-324

Richardson M, Singh G (2003) Observations on the use of the avian chorioallantoic membrane (CAM) model in investigations into angiogenesis. Curr Drug Targets Cardiovasc Haematol Disord $3: 155-185$

Shumko JZ, Defouw DO, Feinberg RN (1988) Vascular histodifferentiation in the chick chorioallantoic membrane: a morphometric study. Anat Rec 220:179-189

Sidis Y, Horseman ND (1993) The hinge region of chicken annexin I contains no site for tyrosine phosphorylation. FEBS Lett 329:296-300

Skalinsky EI, Kondalenko VF (1964) Electron microscopic studies of the chick chorio-allantois during embryogenesis. Acta Morphol Acad Sci Hung 12:247-259

Spanel-Borowski K (1989) The chick chorioallantoic membrane as test system for biocompatible materials. Res Exp Med (Berl) 189:69-75

Sweeny PR, Bather R (1968) An electron microscopic study of the chorioallantoic membrane following infection with Rous sarcoma virus. J Cell Biol 36:299-311

Tuan RS (1980) Calcium transport and related functions in the chorioallantoic membrane of cultured shell-less chick embryos. Dev Biol 74:196-204

Valdes TI, Kreutzer D, Moussy F (2002) The chick chorioallantoic membrane as a novel in vivo model for the testing of biomaterials. J Biomed Mater Res 62:273-282 